\title{
Conclusion
}

\section{Remembering and memorialising}

Memory is fallible; and, because the reader of any memoir knows this, no memoir is fully believed. Yet, some are more convincing than others. Some are taken as faithful renditions of experience; others are recognised as close approximations to 'the truth'; still others have clearly identifiable fictional elements. An author such as Edmund Blunden could write with authority of the terrors of the trenches: of how a lance corporal was reduced by a shell to 'gobbets of blackening flesh', of how an 'excellent sentry' was shot through the head while staring through a loophole. ${ }^{1}$ Nurses, too, could write with authority. Although only a combatant like Blunden could faithfully describe a sudden death or the emotional turmoil of trench life, a nurse such as Alice Fitzgerald could write of the horror of witnessing slow death from wound sepsis or the anxiety of lying in a bell tent during a bombardment with a steel helmet over her face.

Some nurse writers were careful observers and relentless truth-tellers. Others wrote with purpose, some with pacifist intent to show that war was horrific, not heroic. In this way, their work bore some similarities to those of male writers who wanted to draw society's attention to the realities of the trenches. ${ }^{2}$ Yet, in some ways, the writings of nurses were starker, because they bore witness to the suffering that followed battle injury. Rebecca West insisted on demonstrating the way in which war debased those involved in it. Enid Bagnold exposed the dehumanising effects of the military medical 
system. Ellen La Motte - the most shocking of all - offered an exposé of the brutality of war itself, demonstrating how, beneath the surface of its apparent heroism, lurked fear and degradation. Mabel St Clair Stobart interspersed her powerful story with brief reflective homilies on the nature of warfare, while Lesley Smith simply described her patients' injuries with raw immediacy. These writers were, it seems, driven by a need to tell the truth as they saw it. For most, their project appears to have been to remember rather than to memorialise - to show how things really were rather than to cover reality with a heroic gloss. Or perhaps, for them, the truth (as they saw it) was the most honourable memorial to the suffering of their fellow countrymen.

In writing of their nursing work during the First World War, nurses were also composing portraits of themselves. Whilst some seem to have wanted to remain shadowy figures in the background, foregrounding the courage and resilience of their patients, others chose to depict themselves as actors on a world stage. ${ }^{3}$ When they wrote, British women such as the Baroness de T'Serclaes, Sarah Macnaughtan, and Millicent Sutherland were drawing upon narrative tropes current in their own culture. The adventure novels of G. A. Henty and Henry Rider Haggard had long provided a template for male action within the field of enterprise that formed the British Empire. ${ }^{4}$ But girls read these novels too. And if this created a sense of dissonance - because all the heroes were boys - they could turn to a small but burgeoning corpus of 'girl's own adventure' writings. Although limited, this included the novels of Bessie Marchant, whose heroines faced challenge and hardship and experienced 'heroic adventure. ${ }^{5}$ While her plot resolutions often involved marriage, Marchant's heroines frequently displayed the same courage, toughness, and endurance as boys. And although her heroines only 'engaged in adventure out of necessity' to preserve life or prevent crime, they displayed 'physicality and resourceful capability. ${ }^{6}$ When Millicent, Duchess of Sutherland wrote in her diary during the bombardment of Namur that she 'felt as if I were actually living some book of adventure, such as I had read in my youth,' ful cultural influences. For American women, a pioneering cultural trope was dominant. Women such as Julia Stimson and Helen Dore Boylston portrayed themselves as intrepid pioneers, who could meet any challenge with calmness and capability. 


\section{Dutiful daughters of the allied cause}

Those who nursed the allied wounded of the First World War came from a range of backgrounds. Yet most would have viewed themselves as 'genteel' or 'middle class'. The prestige of army nursing meant that places within elite corps such as the QAIMNS and the ANC were reserved for women who were able to afford a good education, and a sound professional training. At the outset of the war it had been impossible to become a volunteer nurse unless one had sufficient funds to pay for a uniform, a minimal training, and one's own travel; these expenses naturally excluded women of lower class. ${ }^{8}$ Hence, many of those who nursed the wounded during the First World War viewed themselves as 'ladies'; and, as such, they were constrained by the expectation that they would be 'ladylike' in their behaviour as well as being steeped in the patriarchal values of their times. It would not have occurred to most female writers to question the masculine authority that dictated their respective governments' entries into the First World War. Nor would it have occurred to them to question the authority of the Army Medical Services, which mobilised their efforts and transferred them - sometimes at a few hours' notice - from one treatment scenario to another.

British and North American nurses had much in common. As Sidonie Smith and Julia Watson observe: 'remembering has a politics.' Nurses who would not have viewed themselves as 'politically minded' wrote memoirs that both reveal a stark reality about the wounding and maiming brought about by warfare, and conceal a political truth about its nature and origin. Kate Luard and Julia Stimson were born several thousand miles and eleven years apart. Yet their backgrounds were remarkably similar. Both belonged to large, middle-class families, with fathers who were prominent clergymen and significant public figures in their localities. ${ }^{10}$ Both were dutiful daughters. Luard's actions, in resigning early from her position within the QAIMNS Reserve, were dictated by the needs of a sick father at home. Stimson's own father, Henry A. Stimson, wrote the foreword to her compilation of letters, and may have been instrumental in securing their publication. Both women, in common with the vast majority of their colleagues, placed themselves very firmly as subordinates within a patriarchal society. Yet both were powerful. Stimson became 
a leading female figure in an essentially masculine wartime world, while the force of Luard's writing ensured that her work was noticed by the military establishment. When published in 1930, Unknown Warriors was preceded by a preface by Field-Marshall Viscount Allenby, formerly Commander of the Third Army. Allenby's words may explain why Luard's earlier work, published in 1915 at one of the most difficult and uncertain periods of the war - a time when the British Government was careful to suppress any writing that could be seen to endanger morale - was allowed to remain in print. ${ }^{11}$ 'I look back', Allenby wrote, 'with admiration on the amazing endurance and self-sacrificing devotion of those Nursing Sisters in their work of mercy. ${ }^{12}$ The writing of nurses such as Luard and Stimson - like their practice - was placed carefully into a humanitarian category, which permitted their readers to view the First World War as one might view a natural disaster - a tidal wave or earthquake. They did not question the wisdom of political or military leaders. Instead, they consciously emphasised both the heroism of soldiers and the redemptive qualities of nursing: a work that, through its devotion, its inherent goodness, and its spirit of self-sacrifice, might rescue humanity from war's horror and degradation.

American nurse Alice Fitzgerald appears to have paid a high personal price for her attachment to duty and her devotion to her soldier patients. She found herself - as a coopted member of the BEF - more or less entrapped within the bounds of her military service. This sense of being confined - of being unable to act with autonomy or determine one's own fate - seems to have been typical of members of the 'official' military nursing services, particularly when on active service overseas. ${ }^{13}$ As a guest member of the BEF in France, Fitzgerald commented on the restrictions of military service, observing that any individual who joins the army 'weaves himself or herself into a cocoon of red tape from which it is impossible to emerge as an individual. ${ }^{14}$ Fitzgerald embraced military service as an opportunity and endured great hardship as a result - and yet appears to have felt the reward that came with the fulfilment of her 'mission'. Eventually, though, she sought the greater freedom of Red Cross service.

Nurses such as Fitzgerald were able to make choices because they were among the most highly trained technical nurses of their day. Their skills and knowledge were in high demand, enabling the pursuit 
of their goals. Fitzgerald desired - above everything else - to make use of her expertise. Nursing itself was her reward, and, for her, the greatest stressors associated with active service were those pressures that prevented the perfect execution of her work. When she retired and moved into the Peabody Home in New York City she sent all her medals and decorations to the Johns Hopkins School of Nursing in Baltimore, declaring that they were 'more properly a credit to her profession than to her personal merit. ${ }^{15}$

\section{Intrepid travelling nurses}

Service, duty, endurance, courage: such concepts resonate through the writings of women who served as nurses during the Great War. The grand ideas that fed those writings, and the exemplars on which they were modelled, suffused the culture of the British and Allied nations in the decades prior to 1914 and provided the fuel that drove whole nations to participate in one of the most destructive conflicts of modern times. They were the ideas of empire, and, for women, they found an outlet in nursing. ${ }^{16}$

Some nurses' narratives are full of danger and adventure. Some involve freedom of movement on a scale previously unknown for most women; and here they differ from male narratives. While the writings of men tell of being led up to the war front and held there either to survive or to be dragged into and destroyed by the war machine, for those female writers not attached to 'official' services, flight was possible and could occur at almost any time. Memoirs such as Violetta Thurstan's Field Hospital and Flying Column have this tone. They are about freedom, not captivity. Nurses who avoided 'official' enlistment, and offered their services, instead, to 'freelance' hospital units or to Red Cross Societies in countries where fully trained nurses were scarce, found that the war afforded them a level of freedom they had never previously experienced. Thurstan's professional training became, effectively, a ticket to travel - to enjoy the opportunities afforded by a qualification from one of London's most prestigious nursing schools. She 'flew' in and out of war nursing, as a bird might fly in and out of a storm. Thurstan appears to have been immensely comfortable with her nursing expertise - to the point at which she felt able to write one of the few technical manuals of wartime nursing to 
be published during the First World War. ${ }^{17}$ After her death, she was buried with her eight medals - clasping to herself forever the reward and honour with which they were infused.

On the Western Front, certain geographical locations took on a symbolic significance, becoming inextricably entangled with narratives of the war itself. Vera Brittain found Etaples a sad place filled with camp hospitals and 'crosses grey. ${ }^{18}$ Even before her arrival in France, by about 1916, certain places had begun to take on a mythic status. At Ypres the ruined Cloth Hall symbolised the destruction of the old civic values. ${ }^{19}$ When Ellen La Motte saw it from a distance, she stood transfixed, commenting later on her sense of awe and dread at finding herself in such proximity to one of the epicentres of war's destruction. ${ }^{20}$ On the Somme, another symbolic structure captured the imagination: a massive gilded statue of the Virgin and Child, dislodged by shelling, which hung from the top of the ruined basilica at Albert. Anxious to attach meaning to what was really only an 'accidentally damaged third rate gilded metal statue', those who saw it chose to believe that it symbolised suffering and sacrifice, and that the war would end when it fell to the ground. ${ }^{21}$ After the war, it was possible to take a 'Cook's Tour' of the affected areas, or to buy a series of Illustrated Michelin Guides to the Battlefields (1914-1918), and visit the devastated zones for oneself. ${ }^{22}$ Writers such as Enid Bagnold and Vera Brittain did spend time touring and recording their experiences. ${ }^{23}$

For Elsie Knocker, the war was an opportunity both to prove her own worth and - ultimately - to test some of her ideas about the treatment of trauma. Her efforts in establishing - with Mairi Chisholm her advanced field dressing station on the Belgian Front won her acclaim and recognition as one of the 'Heroines of Pervyse.' The experience of other adventurous women was - ultimately - altogether bleaker. For Sarah Macnaughtan, her desire to serve on the Persian war front led to her own destruction.

At the outbreak of war, the British Empire was at the height of its powers, and the British people were - as a nation - at the height of their confidence. For a population accustomed to conquering the globe, the war may have presented itself as just another challenge. There had, it seemed, been many wars in the previous five decades: the Zulu War, the Egyptian Crisis, and the Boer Wars, to name a few. Yet, the British project of expanding not only its own empire, 
but also 'the known world' itself, had often ended in misery and failure. Ernest Shackleton had been acclaimed a hero following the failed Trans-Antarctic Expedition of 1914-17, when a dramatic escape from the doomed ship Endurance had made his name. Yet Antarctica was to claim his life when, despite suffering from heart failure, he insisted on returning to the continent in 1920, only to die of a myocardial infarction on board his ship Quest. ${ }^{24}$ For Captain Robert Scott, his achievement in reaching the South Pole on 17 January 1912 was to turn to tragedy when he discovered that not only had he been beaten to his objective by Norwegian Roald Amundsen, but he had also left it too late in the season to be able to return to safety. He and his team died on the return journey. ${ }^{25}$ And on 6 June 1924, two men, George Mallory and Sandy Irvine, set out from a camp on Mount Everest's North Col and were never seen again. ${ }^{26}$ This tendency to test oneself beyond the limits of one's own powers, to attain heroic status while destroying one's own life - although not a peculiarly British trait does seem to have been expressed most powerfully by the British during the early twentieth century. When Sarah Macnaughtan reached home in May 1916, she is said to have remarked to her maid: 'Russia has killed me. ${ }^{27}$ She might as soon have remarked 'The war has killed me'; her determination to be present wherever her experience of war could be at its most intense had led to her destruction. Her death illustrates the fact that women, as well as men, could value a patriotic cause beyond their own lives.

\section{Heretical nurses}

Not all nurse writers saw themselves in uncomplicated terms as part of a civilising force, siding with good against evil. Some wrote with the deliberate intention of destroying the false heroic myths of the First World War and revealing what they saw as its squalid and horrific truths. ${ }^{28}$ Two of the most insistently pacifist writers of the Great War - Mabel St Clair Stobart and Ellen La Motte - were also two of the most highly educated women of their day. Stobart, a member of the British upper-middle class, was wealthy enough to fund her own unit - the Women's Sick and Wounded Convoy Corps - and to travel independently to Serbia. Ellen La Motte was a fully qualified professional nurse; an alumna of the prestigious nurse training school at 
the Johns Hopkins Hospital in Baltimore, she was one of the most independent and radical American nurses of her day. Stobart and La Motte wrote in very different styles, yet they conveyed a similar message: modern warfare was not heroic; it was debasing and destructive to both the physical and moral fibres of its protagonists.

Millionaire philanthropist Mary Borden, who founded and directed a field hospital, 'L'Hôpital Chirurgical Mobile No. 1', published her The Forbidden Zone ten years after the armistice. She declared her writings to be the 'fragments of a great confusion, ${ }^{29}$ and appears to have had no intention of presenting events in tidy chronological order, wishing, rather, to get close to a fragmentary and inchoate 'truth'.

These writers were 'heretics' because they pushed against the received wisdom of their own time. Most were volunteers rather than trained, professional nurses (with the obvious exception of La Motte); and all were women. ${ }^{30}$ They came from a range of national and social class backgrounds. ${ }^{31}$ And yet there are significant similarities among them. All chose to write in ways that were likely to cause shock or offence and all attacked their readership with a relentless insistence that one must not turn away from the realities of war, which are in actual fact disgusting, not heroic.

Some of their works met - not surprisingly - with negative responses in their own times. Enid Bagnold was summarily dismissed from her post as a volunteer nurse soon after the appearance of her Diary without Dates. ${ }^{32}$ La Motte's The Backwash of War was suppressed by the censors in combatant nations soon after its publication. ${ }^{33}$ Rebecca West's War Nurse met with perhaps the most interesting and mysterious fate. Disowned by its own author, it appeared for the first time as a complete piece in 1930 as an anonymous text. ${ }^{34}$ It was only in the last three decades of the twentieth century that these memoirs came to be highly valued. Their rediscovery by women's historians and scholars of literary modernism has assured them a place in the modern 'canon' of the First World War.

The writings of 'heretics' such as Mabel St Clair Stobart and Ellen La Motte contrast with those of better-known authors such as Vera Brittain and Irene Rathbone, who chose to depict both the wounded soldier and the volunteer nurse in a heroic light. Although pacifist in intent and powerful in their effects, the latter refrain from exposing the reader to the more brutal and degrading elements of warfare, 
preferring to emphasise, in Brittain's case, its poignancy and, in Rathbone's, its drama and pathos. ${ }^{35}$ Although, in many ways, the writings of women such as La Motte and Stobart were produced from very similar motives, their deliberate intention to disrupt and disturb the perhaps rather complacent - beliefs of their readership sets them apart from the more traditionalist writings of their contemporaries.

'Heroism' was a contentious notion for nurse writers. Most of those who questioned the validity of war distrusted it as an ideological concept. Although individuals such as Kate Finzi and Stobart chose to recognise it in the way their patients endured pain and suffering, others - notably La Motte - refused to see it as anything other than a false ideology. This refusal is part of an uncompromising attitude to 'the truth', which pervades all of La Motte's writings - from the earliest part of her career, to her latest campaigns against the opium trade. In The Tuberculosis Nurse, when discussing the fact that nurses must inform patients of their diagnosis, she expresses what seems to be an article of faith: 'people are never really injured by being told the truth. ${ }^{36}$ In 'A Joy Ride' she compares soldiers in their hutted encampments to animals in sheds, passively awaiting slaughter, oblivious to the truth about their fate. She is struck by the helpless, driven horses on the Poperinghe-to-Ypres road, with rope over their eyes, protected from shrapnel, but unable to see. When she takes shelter with the Canadians in a 'flimsy hut' she too is protected from stray shrapnel, yet blinded by the darkness; and in that darkness nobody speaks of their fear. ${ }^{37}$ Later, while travelling in the Far East, she develops the metaphor of the Buddha trapped under a wine glass, representing the man who has lost his spirit. ${ }^{38}$ For La Motte only two things mattered: to see clearly and to write the truth.

\section{Autonomy and agency}

Few writers were as uncompromising as La Motte. Many found it difficult to see the conflict as something that had been created and prolonged by human beings. It was easier to regard it as a force of nature, which no-one could have prevented or curtailed. It was, perhaps, for this reason that metaphors of standing close to a great ocean and watching its waves bring in the shattered remnants of soldiers occur frequently. Margaret Deland had the feeling, in the early months of 
war, that 'in Europe the Peoples of all nations [were] rising - rising - rising on the crest of its awful Wave!. ${ }^{39}$ In a similar vein, Sarah Macnaughtan wrote: 'My own experience was much like that of persons who stand on the beach while others put out to sea, and at whose feet pieces of wreck and corpses are thrown up by the tide. ${ }^{40}$

For Maud Mortimer, although the war may be a 'force of nature', its combatants are not merely passively waiting for destruction; their involvement requires an effort of will. For her, the field hospital seems like a sanctuary on the edge of a fierce ocean. Its reception hut catches 'the spindrift of [a] shattered endeavour. ${ }^{41}$ For Mary Borden, in her reception hut on the Somme Front, 'the dying men on the floor were drowned men cast up on the beach, and there was the ebb of life pouring away over them, sucking them away, an invisible tide. ${ }^{42}$ She and her 'old orderlies, like old sea-salts out of a lifeboat' worked to save lives. ${ }^{43}$ Ellen La Motte saw a similar scene from a very different vantage point: L'Hôpital Chirurgical Mobile No. 1 lay in the 'backwash' of war, but into it seeped 'the slime in the shallows. ${ }^{44}$ For most of these nurses, the war was a force against which individual agency was powerless. And yet, all come across in their writings as active, not passive: exercising a limited autonomy. Sarah Macnaughtan - like Violetta Thurstan and Henrietta Tayler - travelled where she chose, endeavouring to save life where she thought she might be most needed. Borden used her wealth to create hospitals and took pride in their low mortality rates. Mabel St Clair Stobart established a mobile unit and placed herself at its head: 'The Lady of the Black Horse'. Her desire was, paradoxically, both to equal the martial prowess of men, and to expose the ultimate worthlessness of their military exploits. Ellen La Motte's desire was equally ambitious - to expose the realities of war. But her work was suppressed and she exercised her own freedom by leaving the continent that was being laid waste and travelling to another, where her campaigning zeal could have an effect.

In June 1917, a column in the BJN asserted that:

never have our nurses been in such danger to life in any previous war, and their calmness and courage will for all time, we hope, disabuse men's minds of the fallacy that British women are devoid of our finest national qualities. Indeed, the women of every nation in every war zone have risen to the sublime heights of valour and daring ... deny them the vote if you dare! ${ }^{45}$ 
It was not only as nurses that women were able to claim such rights. Yet it was as nurses that they pushed forward their claims most forcibly, because nursing gave them a role in warfare that was both acceptable as a feminine pursuit and advantageous as a heroic and intrepid one. Some were able to use nursing as a vehicle that would give them influence and a place in the world at a time when they would, otherwise, have been confined to the domestic scene on the 'home front. ${ }^{46}$ War represented an opportunity for women 'to escape domestic restrictions, to get "out of the cage" ${ }^{47}$

In discussing the cultural changes of the late nineteenth and early twentieth centuries, Sheila Rowbotham has commented that the women who worked to transform both their own lives and the world around them were 'dreamers and adventurers, for they explored with only the sketchiest of maps and they headed towards the unknown courageously' ${ }^{48}$ Nurse writers, more than any other women, moved into the unknown: not only did they enter the 'forbidden zone' of war; they also invented new ways of describing what they found there.

It has been argued that the First World War strengthened nursing through the winning of both female suffrage (in 1918) and a professional register for Britain (in 1919). ${ }^{49}$ Their nursing work, and the experience it offered them, enabled women to take their places among the finest writers of the war - to become part of the literary canon of the twentieth century. It was one of the levers with which they thrust open the doors to civic and political participation, bringing them to prominence and giving them a place and a voice.

\section{The truth about the war}

To capture both the essence and the full reality of what they witnessed was the primary project of most nurse writers. Yet, the existence of both pro-war propaganda and fierce censorship often prevented the fulfilment of that project. ${ }^{50}$ Women such as Millicent Sutherland, whose thinking was deeply influenced by the imperialist values of their time, could write of the heroism and adventure of war without experiencing conflict. Others wrote with difficulty of what they saw; their desire to capture accurately the courage and resilience of their patients was confounded by uncomfortable truths about the war's realities. Some, such as Alice Fitzgerald, entered war believing that 
they were fighting for a noble cause, and came out of it convinced that it had been a horrific waste. Only a few opposed both the patriarchal system and the propaganda of war from the start. Of all the writers discussed in this book, Ellen La Motte is the only one who did so with total confidence, writing incisively about the debasing qualities of warfare. What is most remarkable is the fact that she first published her The Backwash of War in 1916, more than ten years before the powerful witness statements of men such as Erich Maria Remarque, Henri Barbusse, and Robert Graves.

Vera Brittain wrote that 'the truth is so often one of the most difficult things to discover, let alone to impress upon others. ${ }^{51}$ Yet, in Rebecca West's view, truth was not what mattered. Only experience mattered, and Corinne Andrews' experience was that the war was, quite simply, incomprehensible: 'Ç'est comme la guerre. Il ne faut pas chercher à comprendre: It's like the war. You needn't try to understand it. ${ }^{52}$ Some nurses reflected on how naively and innocently they - like their male counterparts - had entered the most destructive conflict that had ever been fought. After her experiences in Belgium, Sarah Macnaughtan recollected the way she and other volunteer nurses had learned their bandaging skills on 'little messenger boys' with 'convenient fractures'. These pseudo-patients had never 'screamed and writhed or prayed for morphia when they were being bandaged. ${ }^{53}$

Nurse writers chose to use their privileged position as part of the military medical machine to compose powerful witness statements about the nature of war. In using this opportunity, grasping it, and transforming it into something more than just a sentimental account of the suffering and bravery of the wounded, these women pushed at the boundaries of their existing social roles, and confounded society's expectations. Their work can be viewed as a statement about the power of women - and more particularly the power of nurses to see with clarity and write with precision about subjects that had previously been exclusively within the domain of men. The fact that women could write the most vivid accounts of wounds, despair, and suffering - that they could, themselves, be endangered and sometimes damaged by war - was a statement about their right to act as participants in the political decision-making that might lead to war. ${ }^{54}$

Going much further than witness statements, these works depict the horror of the First World War: not just the gore and blood, but 
also the existential suffering. Nurse writers clearly wanted the world to share their insights. Some went so far as deliberately to expose propagandist myths. The fact that war was not noble - that it produced horrific outcomes - had come as an unexpected shock to many of them and created a sense of outrage that demanded an emotional outlet. And many appear also to have had a desire to express their sense of the self-transformation that their experiences had brought about. Their writings were about war; they were also about nursing; but, ultimately, they were about the self: as engaged participant, as observing witness, as suffering victim, as powerful and autonomous agent. The nurses of the First World War were the first female generation of the twentieth century: the generation whose experience was forged in the greatest man-made catastrophe of modern times. As such, they were also the generation whose insights would transform the lives not only of their daughters and granddaughters, but of their sons and grandsons too.

\section{Notes}

1 Edmund Blunden, Undertones of War (London: Penguin, 2010 [1928]): 46.

2 Paul Fussell, The Great War and Modern Memory (Oxford: Oxford University Press, 2000 [1975]). On soldiers' writings, see also: Frank Field, British and French Writers of the First World War (Cambridge: Cambridge University Press, 1991); Samuel Hynes, A War Imagined: The First World War and English Culture (London: Pimlico, 1992); Samuel Hynes, The Soldier's Tale: Bearing Witness to a Modern War (London: Penguin, 1998).

3 Sidonie Smith and Julia Watson have observed that life-writing is, in itself, a 'performative act': Sidonie Smith and Julia Watson, Reading Autobiography: A Guide for Interpreting Life Narratives (Minneapolis: University of Minnesota Press, 2010): 61. See also their Chapter 3: 63-102.

4 See, for example: Henry Rider Haggard, King Solomon's Mines (New York: Longmans, Green, 1901 [1885]); Henry Rider Haggard, She (London: Harper and Bros, 1886). G. A. Henty wrote over 100 adventure stories, with overall sales exceeding 25 million: Michelle Smith, 'Adventurous Girls of the British Empire: The Pre-War Novels of Bessie Marchant', The Lion and the Unicorn, 33.1 (2009): 1-25; Claire Tylee, The Great War and Women's Consciousness: Images of Militarism and Womanhood in Women's Writings, 1914-64 (Houndmills and London: Macmillan, 1990): 33.

5 Smith, 'Adventurous Girls': 1-25.

6 Smith, 'Adventurous Girls': 3. 
7 Millicent, Duchess of Sutherland, Six Weeks at the War (London: The Times, 1914): 37-8.

8 Anne Summers, Angels and Citizens: British Women as Military Nurses, 1854-1914 (London: Routledge and Kegan Paul, 1988). On the social class backgrounds of military nurses, see 228; on VADs, see 237-70.

9 Smith and Watson, Reading Autobiography: 24.

10 On Julia Stimson's family background and the position of her father as a 'prominent New York clergyman', see: Kimberly Jensen, Mobilizing Minerva: American Women in the First World War (Urbana and Chicago: University of Illinois Press, 2008): 136.

11 On the censorship of writing during the First World War, see: Tylee, The Great War and Women's Consciousness: 53.

12 Kate Luard, Unknown Warriors: Extracts from the Letters of K. E. Luard, R.R.C., Nursing Sister in France (London: Chatto and Windus, 1930), preface by Field-Marshall Viscount Allenby: vii-ix.

13 Christine Hallett, Containing Trauma: Nursing Work in the First World War (Manchester: Manchester University Press, 2009): 209.

14 Alice Fitzgerald, 'Memoirs', MS987, Box 2, Maryland Historical Society Archives, Baltimore, Maryland; Alice Fitzgerald, unpublished memoirs incorporating war diary, c. 1936, Alice Fitzgerald Papers, Md HR M2633, Md HR M2634, Maryland Historical Society, Baltimore, Maryland.

15 Alice Howell Friedman, 'Fitzgerald, Alice Louise Florence', in Martin Kaufman (ed.), Dictionary of American Nursing Biography (New York: Greenwood Press, 1988): 123. Friedman points out that Fitzgerald had been awarded medals by the governments of Great Britain (Victory Medal), Italy, Poland, Serbia, Hungary, Russia, France (Campaign and Victory Medal, and Médaille d'honneur with rosette), and China. She had also been awarded the International Florence Nightingale Medal (122-3). Friedman omits to mention the Royal Red Cross, second class, which was also awarded by the British Government: Fitzgerald, unpublished memoirs, Chapter 10, unpaginated. Alice Fitzgerald's medals are now held by the Alan Mason Chesney Archives, Johns Hopkins Medical Institutions, Baltimore, Maryland.

16 Anne Marie Rafferty and Diana Solano have shown how these aspirations led nurses to join the Colonial Nursing Association in the early years of the century: Anne Marie Rafferty, 'The Seductions of History and the Nursing Diaspora, Health and History: Journal of the Australian and New Zealand Society for the History of Medicine, 7.2 (2005): 2-6; Anne Marie Rafferty and Diana Solano, 'The Rise and Demise of the Colonial Nursing Service: British Nurses in the Colonies, 1896-1966', Nursing History Review, 15 (2007): $147-54$.

17 Violetta Thurstan, A Text Book of War Nursing (London: G. P. Putnam's Sons, 1917). Only two others are extant: Minnie Goodnow, War Nursing 
(Philadelphia: W. B. Saunders, 1917); M. N. Oxford, Nursing in War Time: Lessons for the Inexperienced (London: Methuen, 1914).

18 Vera Brittain, Testament of Youth: An Autobiographical Study of the Years 1900-1925 (London: Virago Press, 2004 [1933]): 329.

19 Fussell, The Great War and Modern Memory: 40.

20 Ellen N. La Motte, 'A Joy Ride', The Atlantic Monthly, 118 (October 1916): 481-90 (484).

21 Fussell, The Great War and Modern Memory: 131-3 (quote at 131).

22 Fussell, The Great War and Modern Memory: 69; Juliet Nicholson, The Great Silence: 1918-1920. Living in the Shadow of the Great War (London: John Murray, 2009): 122.

23 Enid Bagnold, The Happy Foreigner (London: Virago Press, 1987 [1920]); Brittain, Testament of Youth: 481-2. In Brittain's case, she was visiting her brother Edward's grave in Italy. On travel literature, see: Barbara Brothers and Julia Gergits, British Travel Writers, 1910-1939 (Detroit: Gale, 1998); Angela Jones, 'Romantic Women Travel Writers and the Representation of Everyday Experience', Women's Studies, 26.5 (1997): 497-522; Daniel Kilbride, 'Travel Writing as Evidence with Special Attention to Nineteenth-Century Anglo-America', History Compass, 9.4 (2011): 339-50. On travel writing as part of an imperial project, see Arash Khazeni, 'Across the Black Sands, and the Red: Travel Writing, Nature and the Reclamation of the Eurasian Steppe circa 1850', International Journal of Middle East Studies, 42.4 (2010): 591-614.

24 Frank Hurley, South with Endurance: Shackleton's Antarctic Expedition 1914-1917 (London: Bloomsbury, 2004); Hugh Robert Mill, The Life of Sir Ernest Shackleton (London: William Heinemann, 2006).

25 Edward Ratcliffe Garth Russell Evans, South with Scott (London: Collins, 1949); David Crane, Scott of the Antarctic: A Life of Courage and Tragedy in the Extreme South (London: HarperCollins, 2005).

26 Wade Davies, Into the Silence: The Great War, Mallory, and the Conquest of Everest (New York: Alfred A. Knopf, 2011): 537-54.

27 Sarah Macnaughtan, My War Experiences in Two Continents, ed. Mrs Lionel Salmon [Betty Keays-Young] (London: John Murray, 1919): 257.

28 On the creation of heroic myths of warfare, see: Michael Paris, Warrior Nation: Images of War in British Popular Culture, 1850-2000 (London: Reaktion Books, 2000), passim; Graham Dawson, Soldier Heroes: British Adventure, Empire and the Imagining of Masculinities (London: Routledge, 1994), passim.

29 Mary Borden, The Forbidden Zone (London: William Heinemann, 1929): preface.

30 On the significance of the gendered nature of nursing during the war, see: Miriam Cooke and Angela Woollacott (eds), Gendering War Talk (Princeton, NJ: Princeton University Press, 1993); Helen M. Cooper, Adrienne Auslander Munich, and Susan Merrill Squier (eds), Arms and the Woman: War, Gender and Literary Representation (Chapel Hill: University of 
North Carolina Press, 1989). On nursing and gender, see: Eva Gamarnikow, 'Nurse or Woman: Gender and Professionalism in Reformed Nursing, 1860-1923', in Pat Holden and Jenny Littlewood (eds), Anthropology and Nursing (London: Routledge, 1991): 110-29.

31 Although it should be noted that all were, in some sense, 'middle class', individuals such as Borden, Bagnold, and Stobart were undoubtedly much wealthier than La Motte and West. Most of the writers considered in this section were British, though a few - notably La Motte and Borden - were American. Rebecca West was a British writer, who ghost-wrote the diary of an American nurse.

32 Enid Bagnold, Enid Bagnold's Autobiography (from 1889), introduction by Barbara Willard (London: Century Publishing, 1985 [1969]): 129.

33 Margaret Higonnet, Nurses at the Front: Writing the Wounds of the Great War (Boston, MA: Northeastern University Press, 2001), introduction: xiv; Angela Smith, Women's Writings of the First World War: An Anthology (Manchester: Manchester University Press, 2000): 330.

34 Victoria Glendinning, Rebecca West: A Life (London: Macmillan, 1988 [1987]): 108.

35 Brittain, Testament of Youth, passim; Irene Rathbone, We That Were Young: A Novel (New York: The Feminist Press, 1989): passim.

36 Ellen N. La Motte, The Tuberculosis Nurse: Her Function and Her Qualifications. A Handbook for Practical Workers in the Tuberculosis Campaign. By Ellen N. La Motte, R.N., Graduate of Johns Hopkins Hospital; Former Nurse-in-Chief of the Tuberculosis Division, Health Department of Baltimore, introduction by Louis Hamman, M.D., Physician in Charge, Phipps Tuberculosis Dispensary, Johns Hopkins University (New York and London: G. P. Putnam's Sons and The Knickerbocker Press, 1915): 125.

37 La Motte, 'A Joy Ride'.

38 Ellen N. La Motte, 'Under a Wine Glass', The Century Magazine (December 1918): $150-4$.

39 Margaret Deland, Small Things (New York: D. Appleton, 1919): 57.

40 Sarah Macnaughtan, A Woman's Diary of the War (London: Thomas Nelson and Sons, 1915): 158-9.

41 Maud Mortimer, A Green Tent in Flanders (New York: Doubleday, Page, 1918): 198.

42 Borden, The Forbidden Zone: 143-4.

43 Borden, The Forbidden Zone: 144.

44 Ellen N. La Motte, The Backwash of War: The Human Wreckage of the Battlefield as Witnessed by an American Hospital Nurse (1916): vi.

45 Anon., 'French Flag Nursing Corps', BJN (30 June 1917): 452. See also: Christine E. Hallett, Veiled Warriors: Allied Nurses of the First World War (Oxford: Oxford University Press, 2014): Conclusion. 
46 On the significance of women's participation in the war through the VAD movement, see: Sharon Ouditt, Fighting Forces, Writing Women: Identity and Ideology in the First World War (London: Routledge, 1994): 7-46; Summers, Angels and Citizens.

47 Tylee, The Great War and Women's Consciousness: 243. Tylee is drawing upon the work of Gail Braybon and Penny Summerfield, Out of the Cage: Women's Experiences in Two World Wars (London: Routledge, 2012 [1987]).

48 Sheila Rowbotham, Dreamers of a New Day: Women who Invented the Twentieth Century (London: Verso, 2010): 3.

49 Susan McGann, The Battle of the Nurses: A Study of Eight Women who Influenced the Development of Professional Nursing, 1880-1930 (London: Scutari Press, 1992); Hallett, Veiled Warriors: Conclusion.

50 On censorship, see: Tylee, The Great War and Women's Consciousness: 53. On propaganda, see: Trudi Tate, Modernism, History and the First World War (Manchester: Manchester University Press, 1998): 41-62.

51 Paul Berry and Mark Bostridge, Vera Brittain: A Life (London: Virago Press, 2001): frontispiece.

52 Rebecca West, War Nurse: The True Story of a Woman who Lived, Loved and Suffered on the Western Front (New York: Cosmopolitan Book Corporation, 1930): 71-2.

53 Macnaughtan, A Woman's Diary of the War: 22-3.

54 On the risks taken by nurses, see: Hallett, Containing Trauma: 194-223;

Hallett, Veiled Warriors: passim. 